\title{
Factors Influencing the School Experience of Children with Epilepsy
}

\section{Epilepsili Çocukların Bazı Özelliklerinin Okul Yaşantısına Etkisinin İncelenmesi}

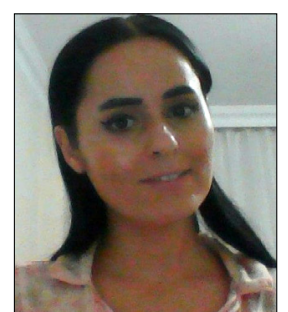

Uzm. Hem. Sevgi ÖZKAN

\section{Sevgi ÖZKAN, ๑ Ayfer AYDIN}

Department of Nursing, Koç University Faculty of Health Sciences, İstanbul, Turkey

\section{Summary}

Objectives: To examine the effects of some characteristics of the epileptic child on school experience, a cross-sectional descriptive study was conducted.

Methods: The data were collected from 110 children with epilepsy between the ages of 10-18 and followed-up by an education and research hospital's neurology clinic in Istanbul. The "Form of the Factors Affecting the School Experience of Children" and the "Parent Form" containing the socio-demographic characteristics of children with epilepsy and their parents were used in the collection of the data.

Results: In our study, we found out that $12.7 \%$ of the children were dropout; $56.4 \%$ were moderately successful and $14.5 \%$ were not good at their lessons; $47.2 \%$ were absent from school for 15 days or more, and $4.5 \%$ repeated a grade level. It was revealed that children with epilepsy have problems with school, friends, and teachers.

Conclusion: Duration of disease and seizure frequency was found to be factors affecting the school experience of the child. The child, family, and teachers were recommended training suitable for the school experience of children with epilepsy.

Keywords: Child; epilepsy; school experience.

\section{Özet}

Amaç: Epilepsili çocuğun bazı özelliklerinin okul yaşantısına etkisinin incelenmesi amacıyla kesitsel bir tanımlayıcı araştırma yapılmıştır.

Gereç ve Yöntem: Veriler, İstanbul'daki bir eğitim ve araştırma hastanesi nöroloji polikliniğe kayıtlı olan 10-18 yaş aralığındaki 110 epilepsili çocuktan toplanmıştır. Araştırma verilerinin toplanmasında epilepsili çocuğun ve ebeveynlerin sosyodemografik özelliklerini içeren "Çocukların Okul Yaşantısını Etkileyen Faktörler Formu" ve "Ebeveyn Formu" kullanılmıştır.

Bulgular: Araştırmamızda çocukların \%12.7'sinin okulu bıraktığı, \%56,4'ünün ders başarısının orta ve \%14.5'inin kötü olduğu, \%47.2'sinin 15 gün ve daha fazla devamsızlık yaptığı ve \% $4.5^{\prime}$ inin sınıf tekrarı yaşadığı bulunmuştur. Epilepsili çocukların okulla, arkadaşlarıyla ve öğretmenleriyle sorunlar yaşadığı saptanmıştır.

Sonuç: Hastalık süresi ve nöbet geçirme sıklığı çocuğun okul yaşantısını etkileyen faktörler olarak saptanmıştır. Çocuğa, aileye ve öğretmenlere epilepsili çocukların okul yaşantısına yönelik eğitimler yapılması önerilmiştir.

Anahtar sözcükler: Çocuk; epilepsi; okul yaşantısı.

\section{Introduction}

Epilepsy is one of the chronic diseases that are common in childhood and adolescence. ${ }^{[1,2]}$ The prevalence of childhood epilepsy ranges from 5.5 to $6.3 / 1,000 .{ }^{[3,4]}$ The prevalence of epilepsy in Turkish children ranges from $5-8 / 1,000 .^{[5,6]}$
Epilepsy is a chronic disease that affects both the child and the family. Depending on the diagnosis and treatment of epilepsy, neurocognitive and psychosocial problems are seen in children. ${ }^{[7-11]}$ These neurocognitive and psychosocial problems affect children's school experience negatively. ${ }^{[2,12,13]}$ 
Children with epilepsy have problems in school experience such as being absent from school, school dropout, grade repetition, academic failure, deterioration and decrease in friendship relations, and inability to adapt to a new group of friends. ${ }^{[1,14,15]}$ Research has found that children with epilepsy have a low school achievement and a high absenteeism and that they leave the school. ${ }^{[16-19]}$

Many factors influence children's school experience. These factors include the age of the child, lack of diagnosis, duration of disease, the severity of disease, the frequency of seizures, parents' education status, and parents' attitudes towards disease. ${ }^{[14,20]}$ There is no study to determine the school experience of children with epilepsy in Turkey. This study aims to determine the effects of some characteristics (gender, age, number of siblings, grade, duration of disease, frequency of seizures, parents' ages, parents' education status, parental working status, and income level of the family) of children with epilepsy on their school experience (attendance to school, achievement status, number of days absent, and grade repetition). In this way, counseling services for children with epilepsy and their families can be planned.

This study aims to;

a. Evaluate the school experience of children with epilepsy (attendance to school, number of days absent, grade repetition, achievement status).

b. Determine the factors affecting school experience of children with epilepsy.

\section{Materials and Methods}

This cross-sectional descriptive study was conducted at the Epilepsy Outpatient Clinic of a training and research hospital in Istanbul between July and August 2017.

\section{Participants}

The inclusion criteria were the following: being between 10 and 18 years of age, having attended school before disease, ability to understand and speak the Turkish language, having over the first 3 months of adaptation to the disease after the diagnosis, being enrolled and monitored in the outpatient clinic and willing to participate in the study. A total of 110 patients fulfilling the inclusion criteria comprised the sample of the study.

\section{Procedures}

After the necessary explanations have been made by the re- searcher, verbal and written consent was obtained from the children who agreed to participate in the study. "The Questionnaire of the Factors Affecting the School Experience of Epilepsy Children" was filled in by the researcher through face to face interviews.

"The Questionnaire of the Factors Affecting the School Experience of Epilepsy Children"

a. The first part of the questionnaire included demographics on the children: age, gender, duration of disease, parents' education and employment status, and number of siblings.

b. The following section contained questions intended to measure the factors affecting the school experience of epilepsy children.

\section{Ethics}

In order to conduct the study, Ethics committee approval was obtained from Koç University Ethics Committee and written permission was obtained from the hospital where the research was conducted.

\section{Results}

\section{Demographic information}

Of the 110 children with epilepsy interviewed, $56.4 \%$ were male, $43.6 \%$ were female and the mean of their age was 12.9 (SD: \pm 2.1 years). $41.7 \%$ of the children $(n=40)$ were in the $6^{\text {th }}$ and $7^{\text {th }}$ grades. $70.9 \%$ of the children $(n=78)$ had at least one sibling.

It was found that $26.4 \%(n=29)$ of the mothers were 33 years old or younger while $30.9 \%$ of the fathers $(n=34)$ were 36 years old or younger. $73.6 \%(n=81)$ of the mothers and $77.3 \%(n=85)$ of the fathers have graduated from a high school. It was also determined that $37.3 \%(n=41)$ of the mothers and $98.2 \%(n=108)$ of the fathers were employed. $53.6 \%(n=59)$ of children with epilepsy were diagnosed at the age of $9-12$ years. It was seen that $59.1 \%(n=65)$ of the children had epilepsy for 2-5 years. $69 \%$ of children with epilepsy $(n=86)$ had at least one seizure per week (Table 1$)$.

\section{Information about school experience of children with epilepsy}

$12.7 \%(n=14)$ of the children with epilepsy were dropouts. It was found that $47.2 \%(n=52)$ of the children with epilepsy who participated in the study were absent from school for 15 days or more and $4.5 \%(n=5)$ repeated their grades. 


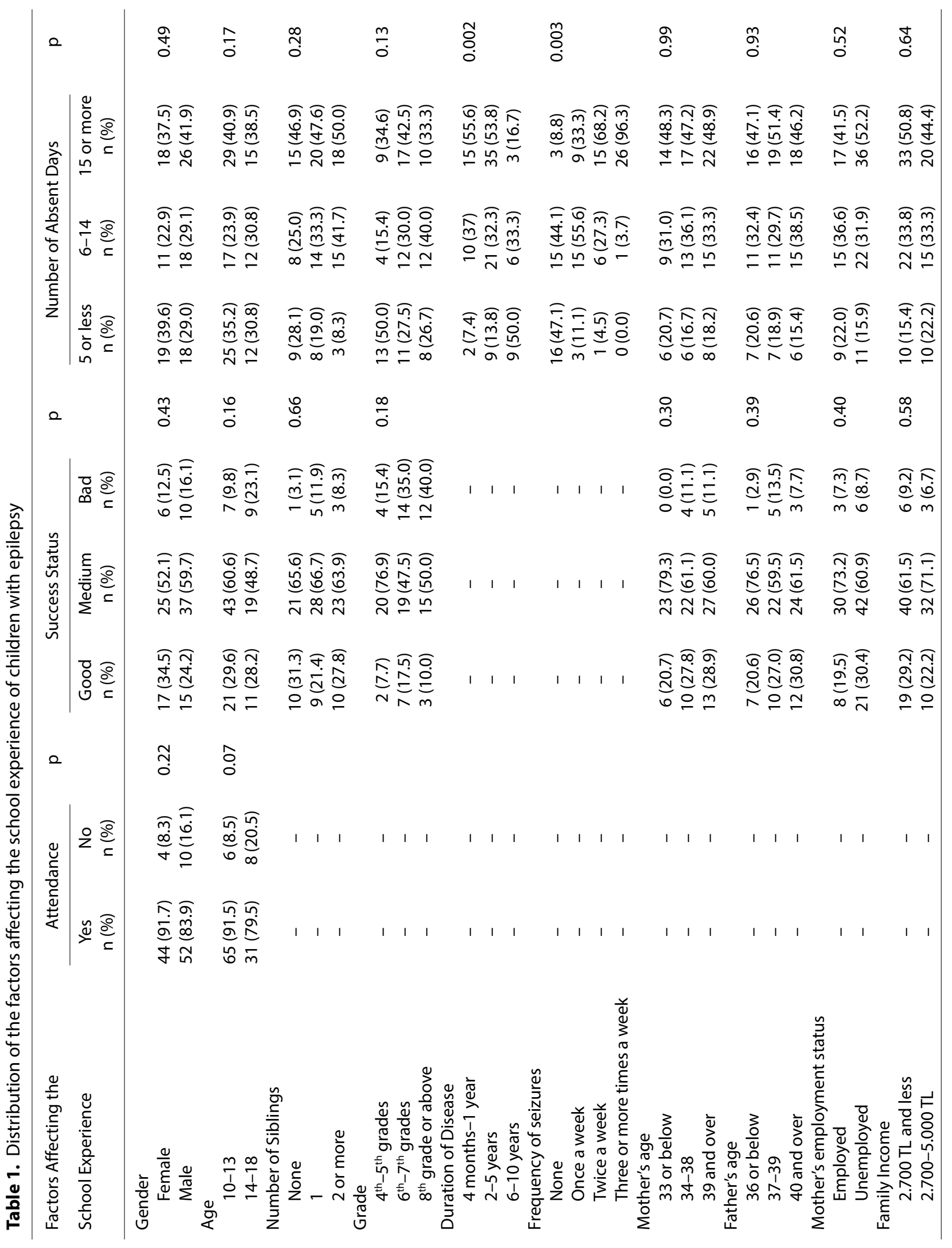


Table 2. Distribution of information on school life of children with epilepsy

\begin{tabular}{lcc}
\hline & $\mathrm{n}$ & $\%$ \\
\hline $\begin{array}{l}\text { Class repetition } \\
\quad \text { Yes }\end{array}$ & 5 & 4.5 \\
$\quad$ No & 105 & 95.5 \\
Problem with school & & \\
$\quad$ Yes & 69 & 62.7 \\
$\quad$ No & 41 & 37.3 \\
Difficulty in understanding lessons & & \\
$\quad$ Yes & 15 & 13.6 \\
$\quad$ No & 95 & 86.4 \\
Friends problem status & & \\
$\quad$ Yes & 21 & 19.1 \\
$\quad$ No & 89 & 80.9 \\
Problems with teachers & & \\
$\quad$ Yes & 7 & 6.4 \\
$\quad$ No & 103 & 93.6 \\
\hline
\end{tabular}

It was determined that $56.4 \%(n=62)$ of the children had a moderate achievement at school and $14.5 \%(n=16)$ had a poor achievement. $85.8 \%$ of the children $(n=12)$ were found to have left school upon their families' request. It was determined that $62.7 \%(n=69)$ of the children had problems with the school, $19.1 \%(n=21)$ with their friends and $6.4 \%(n=7)$ with their teachers. $13.6 \%$ of children with epilepsy stated that they had difficulty in understanding their courses (Table 1, Table 2).

\section{Examination of the factors affecting school experience of children with epilepsy}

The distribution of the factors affecting the school experience of children with epilepsy is shown in Table 1.

There was not a significant relationship between the gender, age, number of siblings, grade, parental age, parental employment status, and income status and school experience (attendance status, success status, number of absent days, grade repetition). A significant relationship $(p<0.05)$ was found between the duration of disease and the number of absent days. It was seen that as the duration of diagnosis increased, the number of days of absenteeism from school decreased. There was a significant relationship $(p<0.05)$ between the frequency of seizures and the number of absent days from school.

It was also seen that as the frequency of seizures increased, the number of absent days from school increased.

\section{Discussion}

\section{Discussion of findings related to the school experience of children with epilepsy leaving school}

The results of our study showed that $12.7 \%$ of the children who participated in the study left the school. In the study conducted in Africa, it was found that $20 \%$ of children with epilepsy left school. ${ }^{[21]}$ In Western Uganda, on the other hand, it was determined that $43.2 \%$ of 162 children with epilepsy left school. ${ }^{[22]}$ Our study points to the fact that although the dropout rate is lower than the rates in the literature, it still cannot be underestimated. Among the reasons for leaving the school, there are reasons such as frequent seizures, the fact that children's families do not send them to school and that the children do not want to go to school. In the study conducted in Africa, it was determined that the reasons for leaving school were frequent seizures, negative attitudes of friends and parental education status. ${ }^{[2]}$ It is possible that parents do not want to send their children to school to protect them.

\begin{abstract}
Absenteeism from school
It was found that $47.2 \%$ of the children participating in the study were absent from school for 15 days or more. When the causes of absenteeism are examined, reasons such as frequent seizures, ongoing treatment, disease, and the fact that the family does not send them to school stand out. In the study conducted in Greece, it was determined that all of the children with epilepsy were absent from school for at least one day and $75 \%$ for 5 days. ${ }^{[13]}$ In a study in Brazil, $88 \%$ were absent from school for at least one day for various reasons. The causes of school absenteeism were identified as seizures, medical appointments and tests related to epilepsy (EEG, MRI, blood work, etc.). ${ }^{[16]}$ In the study conducted in Africa, $51 \%$ of children with epilepsy were absent from school for five days or more per month. ${ }^{[2]}$ It is observed that children with epilepsy have high rates of absenteeism and that the causes such as duration of treatment, seizures, and family attitude have an effect on the school attendance. The protective attitude of the parents may lead to an increase in the absenteeism of the child. School absenteeism can also increase the academic difficulties of the epileptic child.
\end{abstract}

\section{Academic success}

It was determined that $56.4 \%$ of the children had moderate academic success and $14.5 \%$ had poor success. Among the 
reasons for the low academic success of children with epilepsy; distractibility, frequent doctor visits, the inadequate attention of teachers, daytime sleepiness stand out. In a study on the average grade points of epileptic adolescents in Nigeria, $43.8 \%$ of the children were found successful. It was determined that school grades of children with epilepsy are significantly lower than that of healthy children. It was also found that there is a significant relationship between school failure and weak family relationships, adolescents' attitudes towards disease, stigmatization, and duration of disease in epileptic adolescents. ${ }^{[15]}$ In a study of 123 epileptic children in the Indiana state of the United States, the success level of almost half of the children was found to be low. ${ }^{[23]}$ In this systematic study, $72 \%$ of children with epilepsy were found to have low academic success and $42 \%$ were unsuccessful. ${ }^{[24]}$ In the study carried out in Nigerian University Training and Research Hospital Pediatric Neurology Clinic, it was found that $26 \%$ of the children with epilepsy had a low grade point averages. It has been found that academic success is mainly affected by the type of seizure. ${ }^{[25]}$ It is seen that the decrease in the academic success of the children depends on the disease and treatment. It can be said that the academic success of children with epilepsy decreases due to the course of the disease and the side effects of drugs they take.

\section{Problems at school}

$19.1 \%$ of children with epilepsy were found to have problems (exclusion and rejection) with their friends. In the study conducted in Africa, $36 \%$ of the children said that their classmates had a negative attitude towards them. One-third of the children reported that they had problems such as fear, exclusion, and discrimination. In the study conducted in Northern Ethiopia, 16\% of children with epilepsy reported that they were discriminated by their classmates. ${ }^{[26]}$ Negative behaviors of peers are not limited to developing countries. In the study conducted in France, $20 \%$ of children with epilepsy reported that they encountered negative attitudes from their peers. ${ }^{[27]}$ The fact that children with epilepsy are regarded as'different' by others, that epilepsy is considered to be a contagious disease and behavioral disorders of the epileptic child can lead to the negative attitude of their friends. ${ }^{[26,27]}$

$6.4 \%$ of children with epilepsy were found to have problems (lack of information on how to manage seizures, indifference, lack of understanding, etc.) with their teachers. A study in Serbia found that the teachers have the awareness and understanding of epilepsy, but some of the teachers also had negative attitudes. ${ }^{[28]}$ In the study carried out in Turkey, it was determined that primary school teachers' level of knowledge about childhood epilepsy was insufficient and there were serious mistakes in the attitudes and behaviors regarding epilepsy. ${ }^{[29]}$

In our study, problems with teachers were found to be low, but it seems that the studies conducted in the literature found more problems.

\section{Examination of the factors affecting school experience of children with epilepsy}

According to the results of our study, there is a significant relationship between the duration of epilepsy and absence status (Table 1) ( $p=0.002)$. In the study conducted in Greece, the rate of absenteeism was higher in children with epilepsy with disease duration of fewer than 4 years. ${ }^{[13]}$ It can be said that after epilepsy diagnosis, the child's rate of absenteeism from school is high because of the difficulty of getting used to the disease and treatment and as both parents and children get used to the disease over the years, the rate of absenteeism from school decreases.

There is a significant relationship between seizure frequency and absence status in children with epilepsy (Table 1) $(p=0.003)$. It was found that the duration of absenteeism increased as the frequency of seizures increased in children with epilepsy. In the study conducted in Greece, 62.5\% of children with epilepsy who had 2 or more seizures per month were found to have high rates of absenteeism from school. ${ }^{\left[{ }^{13]}\right]}$ In the study conducted in Brazil, it was determined that $88 \%$ of the children were absent from school for at least one day ${ }^{[16]}$ Seizures have an important effect on the child's school attendance and consequently may increase the academic difficulties faced by children with epilepsy. ${ }^{[16,30]}$ In the studies carried out, there is a relationship between the number of seizures and absenteeism, which is similar to our results. As the number of seizures increases, the rate of school absenteeism also increases. Since seizure is a frightening experience for the child and the family, it is possible that the family does not want to send the child to the school.

\section{Conclusion}

As a result, diagnosis and treatment of epilepsy affect the child's school experience. With regard to the disease, there 
are problems such as dropping out of school, absenteeism and decreasing academic achievement. Factors such as duration of disease and seizure frequency were found to be important factors affecting school experience.

It can be said that after epilepsy diagnosis, the child's rate of absenteeism from school is high because of the difficulty of getting used to the disease treatment both parents and children get used to the disease over the years, As the number of seizures increases, the rate of school absenteeism also increases. In order for the child's school experience not to be negatively affected, parents and teachers should be trained about the problems that may arise in the child's school experience. It is recommended that there be school nurses at schools who will be able to counsel children and families and guide them when they encounter problems.

\section{Ethics Committee Approval}

Ethics committee approved.

\section{Peer-review}

Externally peer-reviewed.

\section{Conflict of interest}

The authors declare that they have no conflict of interest.

\section{Authorship Contributions}

Concept: S.Ö., A.A.; Design: S.Ö., A.A.; Supervision: S.Ö., A.A.; Materials: S.Ö., A.A.; Data collection \&/or processing: S.Ö., A.A.; Analysis and/or interpretation: S.Ö., A.A.; Literature search: S.Ö., A.A.; Writing: S.Ö., A.A.; Critical review: S.Ö., A.A.

\section{References}

1. Prasad AN, Sang X, Corbett BA, Burneo JG. Prevalence of childhood epilepsy in Canada. Can J Neurol Sci 2011;38(5):719-22.

2. Pauschek J, Bernhard MK, Syrbe S, Nickel P, Neininger MP, Merkenschlager A, et al. Epilepsy in children and adolescents: Disease concepts, practical knowledge, and coping. Epilepsy Behav 2016;59:77-82. [CrossRef]

3. Russ SA, Larson K, Halfon N. A national profile of childhood epilepsy and seizure disorder. Pediatrics 2012;129(2):256-64.

4. Camfield P, Camfield C. Incidence, prevalence and aetiology of seizures and epilepsy in children. Epileptic Disord 2015;17(2):117-23. [CrossRef]

5. Topbaş M, Ozgün S, Sönmez MF, Aksoy A, Can G, Yavuzyilmaz $A$, et al. Epilepsy prevalence in the 0-17 age group in trabzon, Turkey. Iran J Pediatr 2012;22(3):344-50.

6. Canpolat M, Kumandas S, Poyrazoglu HG, Gumus H, Elmali F, Per $\mathrm{H}$. Prevalence and risk factors of epilepsy among school children in Kayseri City Center, an urban area in Central Anatolia, Turkey. Seizure 2014;23:708-16. [CrossRef]

7. Williams J, Phillips T, Griebel ML, Sharp GB, Lange B, Edgar T, et al.
Patterns of memory performance in children with controlled epilepsy on the CVLT-C. Child Neuropsychology 2001;7(1):15-20.

8. Fastenau PS, Shen J, Dunn DW, Perkins SM, Hermann BP, Austin JK. Neuropsychological predictors of academic underachievement in pediatric epilepsy: moderating roles of demographic, seizure, and psychosocial variables. Epilepsia 2004;45(10):1261-72. [CrossRef]

9. Turky A, Beavis JM, Thapar AK, Kerr MP. Psychopathology in children and adolescents with epilepsy: an investigation of predictive variables. Epilepsy Behav 2008;12(1):136-44. [CrossRef]

10. Wagner JL, Smith GM, Ferguson PL, Wannamaker BB. Caregiver perceptions of seizure severity in pediatric epilepsy. Epilepsia 2009;50(9):2102-9. [CrossRef]

11. Shamsaei F, Cheraghi F, Zamani G. Comparing Mental Health of School-Age Children with and without Epilepsy. Iran J Child Neurol 2016;10(3):35-41.

12. Msall ME, Avery RC, Tremont MR, Lima LC, Rogers ML, Hogan DP. Functional disability and school activity limitations in 41,300 school-age children: Relationship to medical impairments. Pediatrics 2003;111:548-53. [CrossRef]

13. Serdari A, Tsalkidis A, Tripsianis G, Vadikolias K, Chatzimichael A, Piperidou $C$, et al. Epilepsy impact on aspects of school life of children from different cultural populations in Thrace, Greece. Epilepsy \& Behavior 2009;15:344-50. [CrossRef]

14. Aldenkamp AP, Weber B, Overweg-Plandsoen WC, Reijs R, van Mil S. Educational underachievement in children with epilepsy: a model to predict the effects of epilepsy on educational achievement. J Child Neurol 2005;20(3):175-80. [CrossRef]

15. Duggan MB. Epilepsy and its effects on children and families in rural Uganda. Afr Health Sci 2013;13(3):613-23. [CrossRef]

16. Aguiar BV, Guerreiro MM, McBrian D, Montenegro MA. Seizure impact on the school attendance in children with epilepsy. Seizure 2007;16(8):698-702. [CrossRef]

17. Nuhu FT, Fawole JO, Babalola OJ, Ayilara OO, Sulaiman ZT. So-cial consequences of epilepsy: a study of 231 Nigerian patients. Ann Afr Med 2010;9(3):170-5. [CrossRef]

18. Dakwa FE, Mudyahoto T. Impact of epilepsy on children's academic performance. International Journal of Academic Research in Progressive Education and Development 2013;2(1):359-66.

19. Murugupillai R, Wanigasinghe J, Muniyandi R, Arambepola C. Parental concerns towards children and adolescents with epilepsy in Sri Lanka--Qualitative study. Seizure 2016;34:6-11.

20. Uysal S, Ercan T. Epilepsy, sports, psychosocial life. Turkish Pediatry Archive 2005;40:68-71.

21. Ali DB, Tomek M, Lisk DR. The effects of epilepsy on child education in Sierra Leone. Epilepsy Behav 2014;37:236-40. [CrossRef]

22. Adewuya AO, Oseni SB, Okeniyi JA. School performance of Nigerian adolescents with epilepsy. Epilepsia 2006;47(2):415-20.

23. Fastenau PS, Jianzhao Shen, Dunn DW, Austin JK. Academic underachievement among children with epilepsy: proportion exceeding psychometric criteria for learning disability and associated risk factors. J Learn Disabil 2008;41(3):195-207. 
24. Menlove L, Reilly C. Memory in children with epilepsy: a systematic review. Seizure 2015;25:126-35. [CrossRef]

25. Ibekwe RC, Ojinnaka NC, lloeje SO. Factors influencing the academic performance of school children with epilepsy. Journal of Tropical Pediatrics 2007;53(5):338-43. [CrossRef]

26. Gedefa M, Wolde T, Solomon G. Knowledge, attitudes and practices with respect to epilepsy among preparatory school students in Mekelle city, Ethiopia. International Journal of Collaborative Research on Internal Medicine \& Public Health 2012;4(3):203-15.

27. Soria C, Escolano S, El Sabbagh S, Chmura S, Bulteau C, Chiron
C, et al. Behavioral problems, cognitive difficulties and quality of life in children with epilepsy: an analysis of parental concerns. Child Neuropsychol 2012;18(3):209-27. [CrossRef]

28. Vujisic S, Vodopic S. Epilepsy awareness, knowledge and attitudes among secondary school teachers in Montenegro. Srp Arh Celok Lek 2017;21:1-11. [CrossRef]

29. Üçer H, Sucakli MH, Çelik M, Keten HS. Knowledge, attitudes and behaviors of primary school teachers about epilepsy. Cukurova Med J 2016;41(3):491-7. [CrossRef]

30. Reilly C, Neville BG. Academic achievement in children with epilepsy: a review. Epilepsy Res 2011;97(1-2):112-23. [CrossRef] 